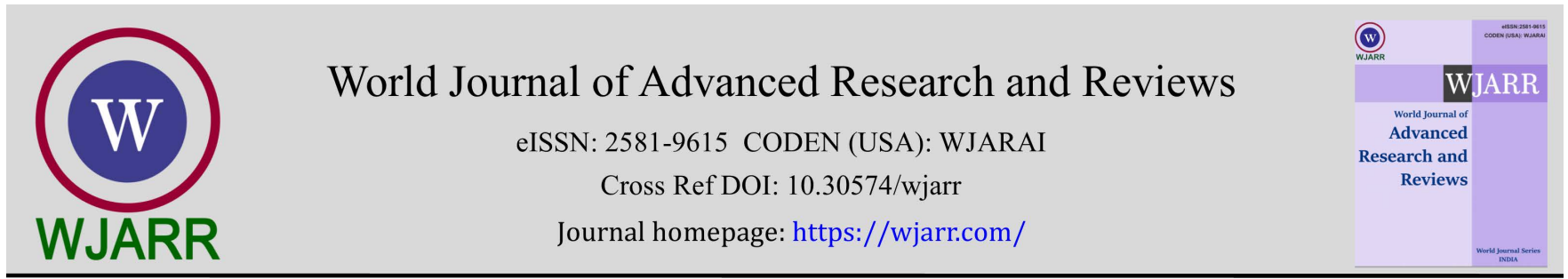

(RESEARCH ARTicle)

Check for updates

\title{
Growth and seedling establishment of tea (Camellia sinensis (L) O. Kuntze) under varying plantain shade in Southwest Nigeria
}

\author{
Seun Adewale Adeosun ${ }^{1,}{ }^{*}$, Adeniyi Olumuyiwa Togun ${ }^{2}$, Kayode Babatunde Adejobi ${ }^{1}$ and Kayode Olufemi \\ Ayegboyin ${ }^{1}$ \\ ${ }^{1}$ Department of Agronomy and Soils, Cocoa Research Institute of Nigeria, P.M.B 5244, Ibadan, Nigeria.
${ }^{2}$ Department of Crop Protection and Environmental Biology, University of Ibadan, Ibadan, Nigeria.
}

World Journal of Advanced Research and Reviews, 2022, 13(01), 638-646

Publication history: Received on 05 November 2021; revised on 19 January 2022; accepted on 21 January 2022

Article DOI: https://doi.org/10.30574/wjarr.2022.13.1.0593

\begin{abstract}
Tea beverage is reputed worldwide for its numerous medicinal and nutritional benefits. Hot and humid climate is a major abiotic constraint to the cultivation of tea in Southwest Nigeria. Planting tea with shade trees has been used to ameliorate the adverse effects of hot climate on tea. A field experiment was carried out in Cocoa Research Institute of Nigeria stations in Ibadan and Owena, Southwest Nigeria to evaluate the growth and seedling establishment of tea plant under plantain shade. Two tea cultivars (C143 and C318) were planted on the field under three shade regimes (two plantain planting densities [1111 plantain ha $\mathrm{h}^{-1}$ and 2222 plantain ha $^{-1}$ ] and control [zero shade]). The experiment was laid out in randomized complete block design arranged in Split-plots with four replications. Data on Number of Leaves (NL), Number of Branches (NB), Leaf Area (LA), Plant Height (PH), Stem Diameter (SD) and Survival Count (SC) were collected and analysed with ANOVA and descriptive statistics at $\alpha_{0.05}$. The results showed that cultivar 143 was significantly better than cultivar 318 in NL, NB, LA, SD and SC in Ibadan and Owena. In Ibadan, plantain density of 2222 increased NL, NB, PH, SD and LA by 24\%, 58\%, 69\%, 89\% and 180\%, respectively in comparison with 1111 plantain ha1 , and by $198 \%, 228 \%, 320 \%, 240 \%$ and $2364 \%$, respectively compared to zero shade. In Owena, 2222 plantain ha-1

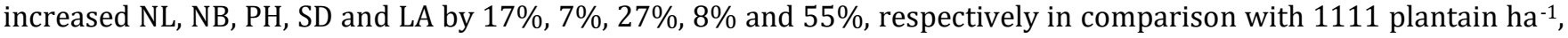
and by $94 \%, 60 \%, 64 \%, 18 \%$ and $106 \%$, respectively compared to zero shade. Highest tea seedling SC of $79.43 \%$ and $78.69 \%$ in Ibadan and Owena, respectively was caused by 2222 plantain ha ${ }^{-1}$. In Ibadan, highest NL (20.06), NB (5.81) and SD (0.53) were recorded in C143 under 1111 plantain ha ${ }^{-1}$; while in Owena, highest NL (82.81), NB (16.56), SD (0.96) and LA (6295.84) were enhanced in C143 under 2222 plantain ha-1. In conclusion, growing tea cultivar 143 under 1111 plantain/ha and 2222 plantain/ha shade densities enhanced its growth and seedling establishment in Ibadan and Owena.
\end{abstract}

Keywords: Plantain shade; Plantain density; Tea cultivar; Growth; Seedling establishment

\section{Introduction}

Tea is the most consumed beverage on earth [1]. It is consumed mainly as black tea (fermented), green tea (nonfermented) or oolong tea (semi-fermented) [2]. Its consumption has a lot of medicinal benefits. Green tea possesses powerful antioxidant which helps to neutralize reactive oxygen species (ROS) [3] and polyphenols [4] which prevents oral diseases, renal failure and cancer [5; 6]. Consumption of tea beverage has been used as treatment for infectious diseases and cold. Since its discovery in China in 2700BC, the cultivation of its plant and drinking of its products have spread to countries like Japan, Russia, India, Sri Lanka, Britain, America and Africa [7]. Today tea plant is cultivated in

\footnotetext{
* Corresponding author: Seun Adewale Adeosun

Department of Agronomy and Soils, Cocoa Research Institute of Nigeria, P.M.B 5244, Ibadan, Nigeria.

Copyright $(2022$ Author(s) retain the copyright of this article. This article is published under the terms of the Creative Commons Attribution Liscense 4.0.
} 
50 countries in all the five continents of the world with major producers being China, India, Kenya, Sri Lanka, Vietnam, Turkey, Indonesia and Iran [8].

The adaptability of tea plant (Camellia sinensis [L] O. Kuntze) is a function of its varieties, environmental and edaphic factors. There are two main varieties of tea: Camellia sinensis var sinensis and Camellia sinesis var assamica [9]. While the former is slow growing and tolerant to cold weather; the latter is fast growing and adaptable to warmer environment. Besides the two varieties above, the following tea varieties have been identified, selected and released to farmers as commercial cultivars on Mambilla highland in Nigeria: 35, 68, 143, 236 and 318 [10; 11]. Cultivars 143 and 318 were outstanding having been adapted to the lowland agro-ecologies of Nigeria [10; 11].

Since its introduction to Nigeria in 1952, tea cultivation has been confined to the highland of Mambilla where its upland varieties are cultivated on commercial scale. Tea is thriving on Mambilla because of its cool climate. However, land for tea cultivation on Mambilla highland is limited by different other agricultural practices and fast expanding urbanization. There is need to expand tea production to other parts of the country, especially the lowland area where the rainfall pattern and the acidic soils are similar to that of the highland. However, among other limiting factors, the hot and humid climate has been a major constraint to the cultivation of tea in Southern Nigeria; hence, the need to provide means of ameliorating the hot weather for enhanced tea cultivation. Shading has been reported to reduce light intensity and its resultant high ambient temperature. The numerous beneficial effects of shading on tea production and products have been documented [12].

Shading exerts positive effects on tea growth and development by reducing photo-inhibition, a common physiological phenomenon in tea when it is grown under full daylight. This explains why tea has been described as a shade loving plant [13]. Moreover, shading has been reported to influence the production of secondary metabolites in tea thereby improving the quality of tea beverage [14; 15] by reducing the flavonoid in tea leaves [16; 17], increasing the theaflavin [18] and the theanine (essential amino acids in tea) contents of tea leaves [19]. Aside from the direct influence of shade on tea plants, the indirect effect of shade in tea production include suppression of weed growth [20], increased soil organic matter [21], reduction of soil erosion [22] and nitrogen fixation especially when it involves planting of leguminous crops [23].

Growing tea and other beverage crops under shade plants is a common agronomic practice in many tea ecologies worldwide. Tea has been intercropped with different shade plants in many of parts of the world to ameliorate the adverse weather conditions. In Nigeria, Iremiren et al. [24] reported that plantain enhanced higher survival count of tea cuttings; eucalyptus has been successfully grown with tea on Mambilla Plateau. Pigeon pea (Cajanus cajan L.) and Glyricidia sepium (Jacq) have been reported to provide shade for growing tea in Sri Lanka and Hawaii [12; 25]. Plantain has been used and recommended as permanent shade for cacao [26]. However, there is dearth of information on the use of plantain as shade plant in field establishment of tea in Nigeria.

Therefore, this trial was conducted to evaluate the effects of different planting densities of plantain on field seedling establishment and vegetative growth of two cultivars of tea plants in Ibadan and Owena, Southwest Nigeria.

\section{Material and methods}

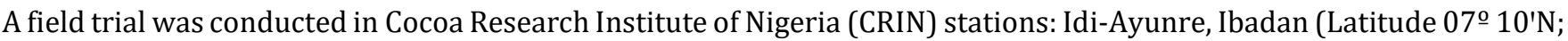
Longitude $03^{\circ} 52^{\prime} \mathrm{E}$ [Tropical rain forest belt]) and Owena (Latitude 07º ; Longitude $05^{\circ} 7^{\prime} \mathrm{E}$ [Humid rain forest belt]), Southwest Nigeria between 2016 and 2018. The locations experience two main seasons: rainy season and dry season. The rainy season is characterized by heavy rains, humid atmosphere and cloudy sky; while dry season is characterized by little or no rainfall, hot and scorching sun and a very low relative humidity. At Ibadan, average maximum and minimum temperature are $27.0^{\circ} \mathrm{C}$ and $19.8^{\circ} \mathrm{C}$, respectively; while relative humidity varies from $89 \%$ during rainy season to $57 \%$ during dry season [27]. At Owena, relative humidity ranges from $89 \%$ during raining season to $76 \%$ during dry season; while average maximum and minimum temperature are $29.9^{\circ} \mathrm{C}$ and $20.7^{\circ} \mathrm{C}$, respectively [28].

The trial was a $2 \times 3$ factorial which comprised two tea cultivars (143 and 318) and three plantain shade levels: 2,222 plantain stands ha-1 ( $3 \times 1.5$ m planting distance); 1 ,111 plantain stands ha ${ }^{-1}$ ( $3 \times 3$ m planting distance); zero plantain as control. The experiment was laid out in Randomized Complete Block Design (RCBD) arranged in Split-Plots with four replications (Blocks). Each block contained 2 main plots and 6 sub-plots: tea cultivars as the main plots and plantain densities as subplots; a gap of $2 \mathrm{~m}$ was allowed between the blocks and adjacent subplots. 
The vegetation on the experimental sites was manually cleared, and plantain suckers were planted 16 months before the transplanting of tea. Tea clonal materials of 143 and 318 cultivars were planted in holes of $20 \times 20 \times 30 \mathrm{~cm}$ dimension at planting distance of $100 \times 60 \mathrm{~cm}$. The tea cuttings were transplanted at 8-11 leaf stage in the avenue of the rows of plantain stands. Weeding was done with hoe and cutlass four times per annum. In the dry season water was artificially applied to the base of the tea plants: Each stand of tea received $2 \mathrm{~L}$ of water 3 times per week. The watering was done between November 2017 and April 2018 while the dry season lasted.

On monthly basis, starting from 3 MAT (Months after transplanting), data were collected on number of leaves, number of branches, plant height, stem diameter and leaf area. At 9 MAT, data on survival count of established tea plants were collected. All data collected from the experiment were analyzed with descriptive statistics and ANOVA using STAR (Statistical Tools for Agricultural Research) [29] statistical software and the significant means were separated with Fishers Least Significant Difference $(\mathrm{P}=0.05)$.

\section{Results and discussion}

Table 1 shows that cultivars 143 and 318 were significantly $(\mathrm{P}=0.05)$ different in their number of leaves at Ibadan and Owena. At Ibadan, cultivar 143 increased in number of leaves from 10.68 at 3 MAT to 16.05 at 12 MAT as against cultivar 318 which increased from 6.32 in number of leaves at 3 MAT to 6.96 at 9 MAT and decreased to 5.92 at 12 MAT. In the same vein. at Owena, number of leaves of C143 increased from 16.50 at 3 MAT to 71.94 at 12 MAT, while that of C318 increased from 9.43 at 3 MAT to 25.99 at 12 MAT. Different plantain densities were significantly $(\mathrm{P}=0.05)$ different in enhancing number leaves of tea plants. Plantain densities at 1111 and 2222 per stand caused significantly higher number of leaves in comparison with zero plantain shade especially at 6-12 MAT in Ibadan and Owena. Plantain density at 2222 plantain ha ${ }^{-1}$ increased number of leaves by $24 \%$ and $198 \%$ compared to 1111 plantain ha-1 and zero shade, respectively at Ibadan, and by $17 \%$ and $94 \%$ at Owena. Tea cultivars were significantly different under all the shade regimes in Ibadan and Owena. However, C143 was superior to C318 in leaf production under the plantain shade and in the zero shade. The highest leaf production was observed in C143 under 2222 plantain stands ha-1.

Branching was significantly ( $\mathrm{P}=0.05)$ higher in cultivar 143 than in 318 (Table 2). Like in number of leaves, there was significant difference between the plantain densities in enhancing the growth of tea branches, with 2222 plantain ha-1 causing the highest number of branches except at 9-12 MAT in Ibadan where 1111 plantain ha-1 was superior to 2222 plantain ha-1. Throughout the sampling periods, unshaded tea produced the least number of branches.

Table 3 reveals that tea cultivars were significantly $(\mathrm{P}=0.05)$ different in their plant heights. Cultivar 143 plants were taller than cultivar 318 in both locations. The difference was significant only at 6-12 MAT in Owena, but not significant $(\mathrm{P}>0.05)$ in Ibadan. Similarly, tea plants grown under plantain shade were taller than those grown in the open (Table 3). At Ibadan, tea plants under 2222 plantain ha-1 increased in height by $320 \%$ and $69 \%$ compared to those grown under 1111 plantain/ha and those grown in the open, respectively; while at Owena, tea plants under 2222 plantain ha-1 increased in height by $64 \%$ and $27 \%$ compared to those grown under 1111 plantain ha-1 and those grown in the open, respectively. Tea plants under plantain steadily increased in height from 3 MAT to 12 MAT in both locations; while in Ibadan, tea plants in the open declined in height from $19.07 \mathrm{~cm}$ at $3 \mathrm{MAT}$ to $8.07 \mathrm{~cm}$ at $12 \mathrm{MAT}$.

In Table 4, C143 was significantly better than C318 in stem diameter at Ibadan and Owena. Tea under 2222 plantain ha${ }^{1}$ were significantly superior to those under zero shade. The same trend was observed in Owena, but the difference was not significant. Similarly, the highest stem diameter was produced in C143 tea under 1111 and 2222 plantain ha ${ }^{-1}$ at Ibadan and Owena, respectively.

The two tea cultivars differ significantly $(\mathrm{P}=0.05)$ in their leaf area under the different plantain shade levels (Table 5). The leaf area of C143 (189.56, 165.66 and 216.76 at 3, 6 and 9 MAT, respectively) were significantly higher than those of C318 (145.15, 140.94 and 162.35 at 3, 6 and 9 MAT, respectively). Similarly, at Owena, the leaf area of C143 (349.66, $412.63,1056.06$ and 4650.05 at 3, 6, 9 and 12 MAT, respectively) were significantly higher than those of C318 (205.32, 276.97, 320.24 and 687.79 at 3, 6, 9 and 12 MAT, respectively). In a similar trend, higher leaf expansion was observed in tea plants grown under plantain shade compared to the unshaded ones. Leaf area of shaded tea plants increased steadily throughout the sampling periods at Owena. However, at Ibadan the leaf area declined temporarily at 6 MAT and later continued to increase at 9 MAT. The 2222 plantain ha-1 significantly enhanced the leaf area of tea plants better

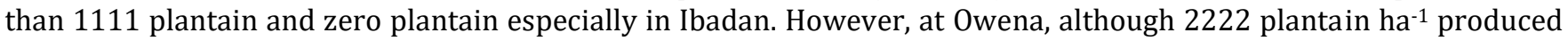
the highest leaf area, it was not significantly different from 1111 plantain ha-1.

The superior leaf growth (number of leaves and leaf area), branching, stem diameter and plant height observed in C143 might be a result of its genetic and morphological characteristics as well as its ability to thrive under harsh tropical 
climate. CRIN [30] had observed C143 to be high yielding, drought tolerant, more adaptable to the lowland and more vigorous in growth than C318. The enhancement of number of leaves, number of branches, stem diameter, plant height and leaf area of tea by shade densities of 2222 and 1111 plantain ha-1 could be due to the moderate light quantum incident on the plants occasioned by different levels of plantain canopy. Subdued light intensities produce cooling effect on both the tea plants and the soil in which the plants grow. The subdued light must have precipitated optimal condition for photosynthesis by regulating leaf and canopy temperature [13]. This result corroborates the report of Hajiboland et al. [31] that tea growth was enhanced under intermediate light intensities. Besides, the shade imposed on the tea plants and their expanded canopies (as a result of moderate light intensities) had ameliorating effect on the soil in which the plants grew. At lower light intensities, soil water is conserved as a result of reduced evaporation, thus making enough water, an important reagent for photosynthesis more readily available for plant use [32].

Table 1 Effects of cultivars and plantain densities on number of leaves of tea plants on the field at Ibadan and Owena

\begin{tabular}{|c|c|c|c|c|c|c|c|c|}
\hline \multirow[b]{2}{*}{ Cultivars } & \multicolumn{4}{|c|}{ Ibadan } & \multicolumn{4}{|c|}{ Owena } \\
\hline & 3 MAT & 6 MAT & 9 MAT & 12 MAT & 3 MAT & 6 MAT & 9 MAT & 12 MAT \\
\hline C143 & $10.68 \mathrm{a}$ & $9.92 \mathrm{a}$ & $12.97 \mathrm{a}$ & $16.05 \mathrm{a}$ & $16.50 \mathrm{a}$ & $21.63 a$ & $40.52 \mathrm{a}$ & $71.94 a$ \\
\hline C318 & $6.32 \mathrm{~b}$ & $6.35 \mathrm{~b}$ & $6.96 \mathrm{~b}$ & $5.92 \mathrm{~b}$ & $9.43 \mathrm{~b}$ & $13.69 \mathrm{~b}$ & $11.71 \mathrm{~b}$ & $25.99 b$ \\
\hline Mean & 8.50 & 8.14 & 9.97 & 10.98 & 12.96 & 17.53 & 26.12 & 48.96 \\
\hline \multicolumn{9}{|c|}{ Plantain densities (Stands ha-1) } \\
\hline 1111 & $8.36 \mathrm{ab}$ & $8.23 \mathrm{~b}$ & $11.81 \mathrm{a}$ & $12.41 \mathrm{a}$ & $13.75 a$ & $19.61 \mathrm{a}$ & $28.36 a$ & $52.86 a$ \\
\hline 2222 & $9.52 \mathrm{a}$ & $10.14 \mathrm{a}$ & $13.91 \mathrm{a}$ & $15.39 a$ & $11.70 \mathrm{~b}$ & $16.77 \mathrm{~b}$ & $31.52 \mathrm{a}$ & $62.03 \mathrm{a}$ \\
\hline Zero shade & $7.62 \mathrm{~b}$ & $6.03 c$ & $4.17 \mathrm{~b}$ & $5.16 \mathrm{~b}$ & $13.44 \mathrm{a}$ & $16.20 \mathrm{~b}$ & $18.87 \mathrm{~b}$ & $32.00 \mathrm{~b}$ \\
\hline Mean & 8.50 & 8.14 & 9.97 & 10.98 & 12.96 & 17.53 & 26.12 & 48.86 \\
\hline \multicolumn{9}{|c|}{$\begin{array}{l}\text { Plantain densities x Cultivars } \\
\text { (Stands ha-1) }\end{array}$} \\
\hline $1111 \mathrm{C} 143$ & $12.09 \mathrm{a}$ & $11.66 \mathrm{a}$ & $14.89 a$ & $20.06 \mathrm{a}$ & $18.31 \mathrm{a}$ & $24.44 \mathrm{a}$ & $41.80 \mathrm{a}$ & $52.19 \mathrm{a}$ \\
\hline C318 & $4.63 \mathrm{~b}$ & $4.81 \mathrm{~b}$ & $12.94 \mathrm{~b}$ & $4.75 b$ & $9.19 \mathrm{a}$ & $14.78 \mathrm{a}$ & $14.93 b$ & $11.81 \mathrm{~b}$ \\
\hline Mean & 8.36 & 8.24 & 13.92 & 12.41 & 13.75 & 19.61 & 28.37 & 32.00 \\
\hline 2222 C143 & $10.69 a$ & $10.28 \mathrm{a}$ & $16.63 a$ & $17.78 \mathrm{a}$ & $14.15 \mathrm{a}$ & $19.72 \mathrm{a}$ & $51.41 \mathrm{a}$ & $82.81 \mathrm{a}$ \\
\hline C318 & $8.34 \mathrm{~b}$ & $10.00 \mathrm{a}$ & $7.00 \mathrm{a}$ & $13.00 \mathrm{a}$ & $9.25 \mathrm{a}$ & $13.81 \mathrm{a}$ & $11.63 \mathrm{~b}$ & $22.91 b$ \\
\hline Mean & 9.52 & 10.14 & 11.82 & 15.39 & 11.70 & 16.77 & 31.52 & 52.86 \\
\hline Zero shade C143 & $9.25 \mathrm{a}$ & $7.81 \mathrm{a}$ & $7.41 \mathrm{a}$ & $10.31 \mathrm{a}$ & $17.03 \mathrm{a}$ & $19.94 \mathrm{a}$ & $28.36 \mathrm{a}$ & $80.81 \mathrm{a}$ \\
\hline C318 & $6.00 \mathrm{~b}$ & $4.25 \mathrm{a}$ & $0.93 \mathrm{~b}$ & $0.00 \mathrm{~b}$ & $9.84 a$ & $12.47 \mathrm{a}$ & $8.58 \mathrm{~b}$ & $43.25 \mathrm{~b}$ \\
\hline Mean & 7.63 & 6.03 & 4.18 & 5.16 & 13.44 & 16.21 & 18.47 & 62.03 \\
\hline
\end{tabular}

There were significant differences in the effects of different tea cultivars and plantain densities on survival count of tea plants at the two locations (Figures 1 and 2). At Ibadan and Owena, C143 was significantly ( $\mathrm{P}=0.05)$ superior to $\mathrm{C} 318$ in survival count. At Ibadan, the survival of tea under 2222 plantain ha-1 was significantly higher than that under 1111 plantain ha ${ }^{-1}$ and zero plantain in the following order: $79.43 \%>32.24 \%>25.74 \%$ for 2222,1111 and zero plantain ha${ }^{1}$ respectively; while at Owena, 2222 plantain ha-1 was better than 1111 plantain ha-1 though not significantly, but was significantly better than zero shade. This implies that plantain shade reduced the scorching effect of adverse weather condition resulting from high ambient temperature [33]. This underscores the fact that tea survival was grossly endangered under full light intensity especially during cloudless dry season when light intensity was at its brightest with the accompanying excessive rise in ambient temperature. Cultivar 143 survived better than 318 under 1111,2222 and zero plantain shade conditions; its survival was significantly $(\mathrm{P}=0.05)$ different at Ibadan, especially under 1111 and zero plantain as against the situation at Owena, where the two cultivars were not significantly different under each plantain shade environment. The result of the interaction of cultivars with the different plantain densities shows that under all the plantain densities, C143 was better than C318 in enhancing seedling establishment, with the highest survival counts of $82.81 \%$ and $92.71 \%$ at Ibadan and Owena, respectively under 2222 plantain density. This was as a result of better ability of $\mathrm{C} 143$ to withstand wide range of ambient temperature [34]. Generally, tea plants survived the first dry season and performed better in vegetative growth in Owena than in Ibadan probably because Owena is located in humid forest zone with higher relative humid than Ibadan. The higher relative humidity in Owena could have slowed 
down the rate of evapotranspiration, thus reducing dehydration and wilting of tea plants as well as enhancing their survival in the hot season.

Table 2 Effects of cultivars and plantain densities on number of branches of tea plants on the field at Ibadan and Owena

\begin{tabular}{|c|c|c|c|c|c|c|c|c|}
\hline \multirow[b]{2}{*}{ Cultivars } & \multicolumn{4}{|c|}{ Ibadan } & \multicolumn{4}{|c|}{ Owena } \\
\hline & 3 MAT & 6 MAT & 9 MAT & 12 MAT & 3 MAT & 6 MAT & 9 МАТ & 12 MAT \\
\hline C143 & $2.06 \mathrm{a}$ & $2.89 \mathrm{a}$ & $3.09 \mathrm{a}$ & $4.43 \mathrm{a}$ & $2.35 \mathrm{a}$ & $3.34 \mathrm{a}$ & $8.35 \mathrm{a}$ & $14.12 \mathrm{a}$ \\
\hline C318 & $1.55 \mathrm{~b}$ & $0.79 \mathrm{~b}$ & $0.87 \mathrm{~b}$ & $2.52 \mathrm{~b}$ & $1.48 \mathrm{~b}$ & $1.74 \mathrm{~b}$ & $3.94 \mathrm{~b}$ & $6.32 \mathrm{~b}$ \\
\hline Mean & 1.81 & 1.84 & 2.98 & 3.47 & 1.92 & 2.54 & 6.15 & 10.22 \\
\hline \multicolumn{9}{|c|}{ Plantain densities (Stands ha-1) } \\
\hline 1111 & $2.67 \mathrm{a}$ & $2.36 \mathrm{a}$ & $2.05 \mathrm{~b}$ & $3.41 \mathrm{~b}$ & $2.53 a$ & $2.73 a$ & $7.46 a$ & $11.22 \mathrm{a}$ \\
\hline 2222 & $1.66 \mathrm{ab}$ & $2.47 \mathrm{a}$ & $3.31 \mathrm{a}$ & $5.38 \mathrm{a}$ & $1.61 \mathrm{~b}$ & $2.64 \mathrm{a}$ & $5.82 \mathrm{~b}$ & $11.98 \mathrm{a}$ \\
\hline Zero shade & $1.09 \mathrm{~b}$ & $0.69 \mathrm{~b}$ & $0.58 \mathrm{c}$ & $1.64 \mathrm{c}$ & $1.63 \mathrm{~b}$ & $2.25 \mathrm{a}$ & $5.16 \mathrm{~b}$ & $7.47 \mathrm{~b}$ \\
\hline Mean & 1.81 & 1.84 & 1.98 & 3.47 & 1.92 & 2.54 & 6.15 & 10.22 \\
\hline \multicolumn{9}{|c|}{$\begin{array}{l}\text { Plantain densities x Cultivars } \\
\text { (Stands ha-1) }\end{array}$} \\
\hline $1111 \mathrm{C} 143$ & $3.59 \mathrm{a}$ & $4.22 \mathrm{a}$ & $3.78 \mathrm{a}$ & $5.81 \mathrm{a}$ & $3.25 \mathrm{a}$ & $3.47 \mathrm{a}$ & $9.63 a$ & $10.19 \mathrm{a}$ \\
\hline C318 & $1.75 \mathrm{a}$ & $0.5 \mathrm{~b}$ & $0.31 \mathrm{~b}$ & $1.00 \mathrm{~b}$ & $1.81 \mathrm{a}$ & $2.00 \mathrm{a}$ & $5.30 \mathrm{~b}$ & $4.75 \mathrm{a}$ \\
\hline Mean & 2.37 & 2.36 & 2.05 & 3.41 & 2.53 & 2.74 & 7.47 & 7.47 \\
\hline $2222 \mathrm{C} 143$ & $1.41 \mathrm{a}$ & $3.25 \mathrm{a}$ & $4.45 \mathrm{a}$ & $5.44 a$ & $1.88 \mathrm{a}$ & $3.63 a$ & $8.77 \mathrm{a}$ & $16.56 a$ \\
\hline $\mathrm{C} 318$ & $1.91 \mathrm{a}$ & $1.69 \mathrm{~b}$ & $2.17 \mathrm{~b}$ & $5.31 \mathrm{a}$ & $1.34 \mathrm{a}$ & $1.66 a$ & $2.88 \mathrm{~b}$ & $5.88 \mathrm{a}$ \\
\hline Mean & 1.66 & 2.47 & 3.31 & 5.38 & 1.61 & 2.65 & 5.83 & 11.22 \\
\hline Zero shade C143 & $1.18 \mathrm{a}$ & $1.19 \mathrm{a}$ & $1.03 \mathrm{a}$ & $2.03 a$ & $1.94 \mathrm{a}$ & $2.94 \mathrm{a}$ & $6.66 \mathrm{a}$ & $15.63 a$ \\
\hline C318 & $1.00 \mathrm{a}$ & $0.19 \mathrm{~b}$ & $0.13 \mathrm{~b}$ & $0.00 \mathrm{a}$ & $1.28 \mathrm{a}$ & $1.56 \mathrm{a}$ & $3.60 \mathrm{~b}$ & $8.34 \mathrm{a}$ \\
\hline Mean & 1.09 & 0.69 & 0.58 & 1.02 & 1.61 & 2.25 & 5.13 & 11.99 \\
\hline
\end{tabular}

Table 3 Effects of cultivars and plantain densities on plant height of tea plants on the field at Ibadan and Owena

\begin{tabular}{|c|c|c|c|c|c|c|c|c|}
\hline \multirow[b]{2}{*}{ Cultivars } & \multicolumn{4}{|c|}{ Ibadan } & \multicolumn{4}{|c|}{ Owena } \\
\hline & 3 MAT & 6 MAT & 9 MAT & 12 MAT & 3 MAT & 6 MAT & 9 MAT & 12 MAT \\
\hline C143 & $18.67 \mathrm{a}$ & $21.51 \mathrm{a}$ & $20.22 \mathrm{a}$ & $22.70 \mathrm{a}$ & $27.83 a$ & $31.96 \mathrm{a}$ & $52.82 \mathrm{a}$ & $79.46 \mathrm{a}$ \\
\hline C318 & $19.47 \mathrm{a}$ & $18.82 \mathrm{a}$ & $17.24 \mathrm{a}$ & $18.67 \mathrm{a}$ & $24.98 \mathrm{a}$ & $27.17 \mathrm{~b}$ & $27.68 \mathrm{~b}$ & $51.08 \mathrm{~b}$ \\
\hline Mean & 19.07 & 20.16 & 18.73 & 20.68 & 26.40 & 29.56 & 40.25 & 65.27 \\
\hline \multicolumn{9}{|c|}{ Plantain densities (Stands ha-1) } \\
\hline 1111 & $18.66 \mathrm{a}$ & $19.15 \mathrm{~b}$ & $17.11 \mathrm{~b}$ & $20.05 \mathrm{~b}$ & $26.96 \mathrm{a}$ & $30.84 a$ & $41.77 \mathrm{ab}$ & $64.21 \mathrm{~b}$ \\
\hline 2222 & $19.24 \mathrm{a}$ & $26.60 \mathrm{a}$ & $27.86 a$ & $33.93 a$ & $26.30 \mathrm{a}$ & $30.42 \mathrm{a}$ & $45.97 \mathrm{a}$ & $81.73 a$ \\
\hline Zero shade & 19.30 & $14.74 \mathrm{~b}$ & 11.21 & $8.07 \mathrm{c}$ & $25.94 \mathrm{a}$ & $27.42 \mathrm{a}$ & $33.02 \mathrm{~b}$ & $49.86 \mathrm{~b}$ \\
\hline Mean & 19.07 & 20.16 & 18.73 & 20.68 & 26.40 & 29.56 & 40.25 & 65.27 \\
\hline \multicolumn{9}{|c|}{$\begin{array}{l}\text { Plantain densities x Cultivars } \\
\text { (Stands ha-1) }\end{array}$} \\
\hline $1111 \mathrm{C} 143$ & $21.44 a$ & $24.16 \mathrm{a}$ & $21.03 a$ & $21.94 \mathrm{a}$ & $28.19 \mathrm{a}$ & $31.86 \mathrm{a}$ & $52.10 \mathrm{a}$ & $59.32 \mathrm{a}$ \\
\hline C318 & $15.89 \mathrm{~b}$ & $14.14 \mathrm{~b}$ & $13.19 \mathrm{a}$ & $18.17 \mathrm{a}$ & $25.73 a$ & $29.83 a$ & $31.43 a$ & $40.40 \mathrm{a}$ \\
\hline Mean & 18.67 & 19.15 & 17.11 & 20.06 & 26.96 & 30.85 & 41.77 & 49.86 \\
\hline 2222 C143 & $17.28 \mathrm{a}$ & $20.83 b$ & $23.78 \mathrm{a}$ & $30.03 a$ & $27.26 \mathrm{a}$ & $36.10 \mathrm{a}$ & $63.57 \mathrm{a}$ & $81.78 a$ \\
\hline
\end{tabular}




\begin{tabular}{|l|l|l|l|l|l|l|l|l|}
\hline C318 & $21.20 \mathrm{a}$ & $32.38 \mathrm{a}$ & $30.94 \mathrm{a}$ & $37.83 \mathrm{a}$ & $25.34 \mathrm{a}$ & $24.74 \mathrm{a}$ & $28.36 \mathrm{a}$ & $46.64 \mathrm{a}$ \\
\hline Mean & 19.24 & 26.61 & 27.36 & 33.93 & 26.30 & 30.42 & 45.97 & 64.21 \\
\hline Zero shade C143 & $17.28 \mathrm{a}$ & $19.54 \mathrm{a}$ & $14.84 \mathrm{a}$ & $16.14 \mathrm{a}$ & $28.03 \mathrm{a}$ & $27.91 \mathrm{a}$ & $42.79 \mathrm{a}$ & $97.26 \mathrm{a}$ \\
\hline C318 & $21.33 \mathrm{a}$ & $9.94 \mathrm{~b}$ & $7.59 \mathrm{a}$ & $0.00 \mathrm{a}$ & $23.86 \mathrm{a}$ & $26.94 \mathrm{a}$ & $23.25 \mathrm{a}$ & $66.20 \mathrm{a}$ \\
\hline Mean & 19.31 & 14.74 & 11.22 & 8.07 & 25.95 & 27.43 & 33.02 & 81.73 \\
\hline
\end{tabular}

Means followed by the same letters in a column under a treatment are not significantly different by LSD (P=0.05)

Table 4 Effects of cultivars and plantain densities on stem diameter of tea plants on the field at Ibadan and Owena

\begin{tabular}{|c|c|c|c|c|c|c|c|c|}
\hline \multirow[b]{2}{*}{ Cultivars } & \multicolumn{4}{|c|}{ Ibadan } & \multicolumn{4}{|c|}{ Owena } \\
\hline & 3 MAT & 6 MAT & 9 MAT & 12 MAT & 3 MAT & 6 MAT & 9 MAT & 12 MAT \\
\hline C143 & $0.34 \mathrm{a}$ & $0.33 a$ & $0.30 \mathrm{a}$ & $0.44 a$ & $0.38 \mathrm{a}$ & $0.44 a$ & $0.53 a$ & $0.85 a$ \\
\hline C318 & $0.31 \mathrm{~b}$ & $0.25 b$ & $0.27 \mathrm{a}$ & $0.19 \mathrm{~b}$ & $0.39 \mathrm{a}$ & $0.35 b$ & $0.36 \mathrm{~b}$ & $0.58 \mathrm{~b}$ \\
\hline Mean & 0.33 & 0.29 & 0.29 & 0.32 & 0.38 & 0.40 & 0.45 & 0.72 \\
\hline \multicolumn{9}{|c|}{ Plantain densities (Stands ha-1) } \\
\hline 1111 & $0.32 \mathrm{a}$ & $0.26 \mathrm{~b}$ & $0.20 \mathrm{~b}$ & $0.27 \mathrm{~b}$ & $0.38 \mathrm{a}$ & $0.45 \mathrm{a}$ & $0.50 \mathrm{a}$ & $0.71 \mathrm{a}$ \\
\hline 2222 & $0.34 \mathrm{a}$ & $0.35 \mathrm{a}$ & $0.40 \mathrm{a}$ & $0.51 \mathrm{a}$ & $0.41 \mathrm{a}$ & $0.47 \mathrm{a}$ & $0.61 \mathrm{a}$ & $0.77 \mathrm{a}$ \\
\hline Zero shade & $0.32 \mathrm{a}$ & $0.24 \mathrm{~b}$ & $0.26 \mathrm{~b}$ & $0.15 b$ & $0.35 \mathrm{a}$ & $0.39 \mathrm{a}$ & $0.49 a$ & $0.65 a$ \\
\hline Mean & 0.33 & 0.28 & 0.29 & 0.30 & 0.38 & 0.44 & 0.53 & 7.1 \\
\hline \multicolumn{9}{|c|}{$\begin{array}{l}\text { Plantain densities x Cultivars } \\
(\text { Stands ha-1) }\end{array}$} \\
\hline $1111 \mathrm{C} 143$ & $0.37 \mathrm{a}$ & $0.35 a$ & $0.27 \mathrm{a}$ & $0.54 \mathrm{a}$ & $0.38 \mathrm{a}$ & $0.45 a$ & $0.50 \mathrm{a}$ & $0.88 \mathrm{a}$ \\
\hline C318 & $0.27 \mathrm{~b}$ & $0.18 \mathrm{~b}$ & $0.13 \mathrm{~b}$ & $0.00 \mathrm{~b}$ & $0.38 \mathrm{a}$ & $0.38 \mathrm{a}$ & $0.39 \mathrm{~b}$ & $0.55 b$ \\
\hline Mean & 0.32 & 0.44 & 0.27 & 0.27 & 0.38 & 0.42 & 0.45 & 0.72 \\
\hline 2222 C143 & $0.35 a$ & $0.31 \mathrm{~b}$ & $0.37 \mathrm{a}$ & $0.50 \mathrm{a}$ & $0.40 \mathrm{a}$ & $0.47 \mathrm{a}$ & $0.61 \mathrm{a}$ & $0.96 a$ \\
\hline C318 & $0.33 a$ & $0.41 \mathrm{a}$ & $0.42 \mathrm{a}$ & $0.52 \mathrm{a}$ & $0.42 \mathrm{a}$ & $0.37 \mathrm{a}$ & $0.38 \mathrm{~b}$ & $0.58 \mathrm{~b}$ \\
\hline Mean & 0.34 & 0.36 & 0.40 & 0.51 & 0.41 & 0.42 & 0.50 & 0.77 \\
\hline Zero shade C143 & $0.32 \mathrm{a}$ & $0.33 a$ & $0.26 \mathrm{a}$ & $0.27 \mathrm{a}$ & $0.36 \mathrm{a}$ & $0.39 a$ & $0.49 \mathrm{a}$ & $0.70 \mathrm{a}$ \\
\hline C318 & $0.32 \mathrm{a}$ & $0.16 \mathrm{~b}$ & $0.26 \mathrm{a}$ & $0.00 \mathrm{~b}$ & $0.36 \mathrm{a}$ & $0.31 \mathrm{a}$ & $0.38 \mathrm{~b}$ & $0.60 \mathrm{a}$ \\
\hline Mean & 0.32 & 0.25 & 0.26 & 0.14 & 0.36 & 0.35 & 0.44 & 0.65 \\
\hline
\end{tabular}

Means followed by the same letters in a column under a treatment are not significantly different by LSD (P=0.05)

Table 5 Effects of cultivars and plantain densities on leaf area of tea plants on the field at Ibadan and Owena

\begin{tabular}{|l|l|l|l|l|l|l|l|l|}
\hline & \multicolumn{5}{|c|}{ Ibadan } & \multicolumn{5}{c|}{ Owena } \\
\hline Cultivars & 3 MAT & 6 MAT & 9 MAT & 12 MAT & 3 MAT & 6 MAT & 9 MAT & 12 MAT \\
\hline C143 & $189.56 \mathrm{a}$ & $165.66 \mathrm{a}$ & $216.76 \mathrm{a}$ & $361.32 \mathrm{a}$ & $349.66 \mathrm{a}$ & $412.63 \mathrm{a}$ & $1056.06 \mathrm{a}$ & $4650.05 \mathrm{a}$ \\
\hline C318 & $145.15 \mathrm{~b}$ & $140.94 \mathrm{~b}$ & $162.35 \mathrm{~b}$ & $242.73 \mathrm{a}$ & $205.32 \mathrm{~b}$ & $276.97 \mathrm{~b}$ & $320.24 \mathrm{~b}$ & $687.79 \mathrm{~b}$ \\
\hline Mean & 167.36 & 153.30 & 189.55 & 302.03 & 277.49 & 344.80 & 688.15 & 2668.92 \\
\hline Plantain densities (Stands ha-1) \\
\hline 1111 & $163.10 \mathrm{~b}$ & $159.81 \mathrm{~b}$ & $209.31 \mathrm{~b}$ & $231.58 \mathrm{~b}$ & $279.37 \mathrm{a}$ & $362.87 \mathrm{a}$ & $690.78 \mathrm{ab}$ & $2427.04 \mathrm{ab}$ \\
\hline 2222 & $193.70 \mathrm{a}$ & $259.47 \mathrm{a}$ & $333.20 \mathrm{a}$ & $648.19 \mathrm{a}$ & $263.83 \mathrm{a}$ & $371.17 \mathrm{a}$ & $908.55 \mathrm{a}$ & $3755.09 \mathrm{a}$ \\
\hline
\end{tabular}


World Journal of Advanced Research and Reviews, 2022, 13(01), 638-646

\begin{tabular}{|l|l|l|l|l|l|l|l|l|}
\hline Zero shade & $145.27 \mathrm{~b}$ & $40.63 \mathrm{c}$ & $26.16 \mathrm{c}$ & $26.31 \mathrm{c}$ & $283.27 \mathrm{a}$ & $300.36 \mathrm{a}$ & $465.12 \mathrm{~b}$ & $1824.63 \mathrm{~b}$ \\
\hline Mean & 167.36 & 153.30 & 189.55 & 302.03 & 277.49 & 344.80 & 688.15 & 2668.92 \\
\hline $\begin{array}{l}\text { Plantain densities x Cultivars } \\
\text { (Stands ha-1 } \text { ) }\end{array}$ \\
\hline 1111 C143 & $217.32 \mathrm{a}$ & $213.81 \mathrm{a}$ & $328.17 \mathrm{a}$ & $321.38 \mathrm{a}$ & $376.58 \mathrm{a}$ & $369.74 \mathrm{a}$ & $917.62 \mathrm{a}$ & $4423.06 \mathrm{a}$ \\
\hline C318 & $108.89 \mathrm{~b}$ & $105.80 \mathrm{~b}$ & $338.21 \mathrm{a}$ & $141.78 \mathrm{~b}$ & $182.16 \mathrm{a}$ & $356.00 \mathrm{a}$ & $463.94 \mathrm{a}$ & $431.02 \mathrm{~b}$ \\
\hline Mean & 163.11 & 159.81 & 333.19 & 231.58 & 279.37 & 362.87 & 690.78 & 2427.04 \\
\hline 2222 C143 & $173.04 \mathrm{a}$ & $227.10 \mathrm{a}$ & $284.72 \mathrm{a}$ & $709.97 \mathrm{a}$ & $339.71 \mathrm{a}$ & $473.10 \mathrm{a}$ & $1529.33 \mathrm{a}$ & $6295.84 \mathrm{a}$ \\
\hline C318 & $214.36 \mathrm{a}$ & $291.84 \mathrm{a}$ & $133.89 \mathrm{~b}$ & $586.41 \mathrm{a}$ & $199.96 \mathrm{a}$ & $269.24 \mathrm{a}$ & $287.78 \mathrm{~b}$ & $1214.34 \mathrm{~b}$ \\
\hline Mean & 193.70 & 259.47 & 209.31 & 648.19 & 269.84 & 371.17 & 908.56 & 3755.09 \\
\hline $\begin{array}{l}\text { Zero C143 } \\
\text { shade }\end{array}$ & $178.33 \mathrm{a}$ & $56.08 \mathrm{a}$ & $37.37 \mathrm{a}$ & $52.63 \mathrm{a}$ & $332.69 \mathrm{a}$ & $395.06 \mathrm{a}$ & $721.24 \mathrm{a}$ & $3231.25 \mathrm{a}$ \\
\hline C318 & $112.21 \mathrm{a}$ & $25.19 \mathrm{a}$ & $14.95 \mathrm{a}$ & $0.00 \mathrm{a}$ & $233.86 \mathrm{a}$ & $205.67 \mathrm{a}$ & $209.01 \mathrm{~b}$ & $418.10 \mathrm{~b}$ \\
\hline Mean & 145.27 & 40.64 & 26.16 & 26.32 & 283.28 & 300.67 & 465.13 & 1824.68 \\
\hline
\end{tabular}

Means followed by the same letters in a column under a treatment are not significantly different by LSD (P=0.05)
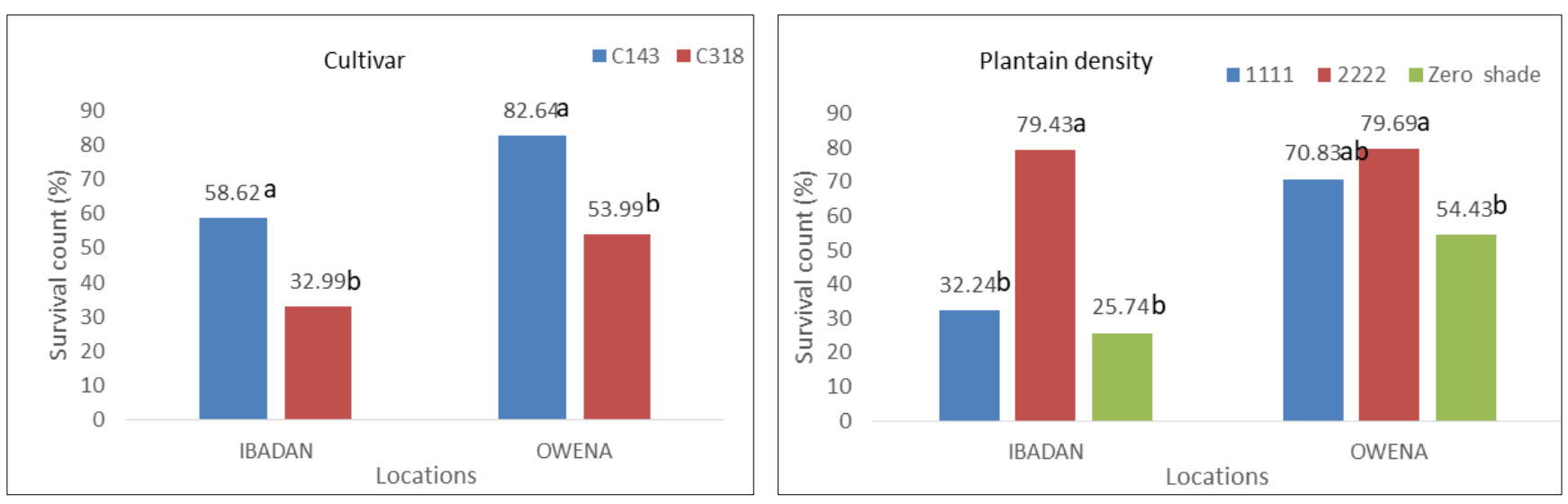

Means followed by the same letters in each composite graph are not significantly different by LSD (P=0.05)

C143: cultivar 143; C318: cultivar 318; 1111:1111 plantain stands/ha; 2222: 2222 plantain stands/ha

Figure 1 Main effects of cultivar and plantain density on survival count of tea plants at Ibadan and Owena
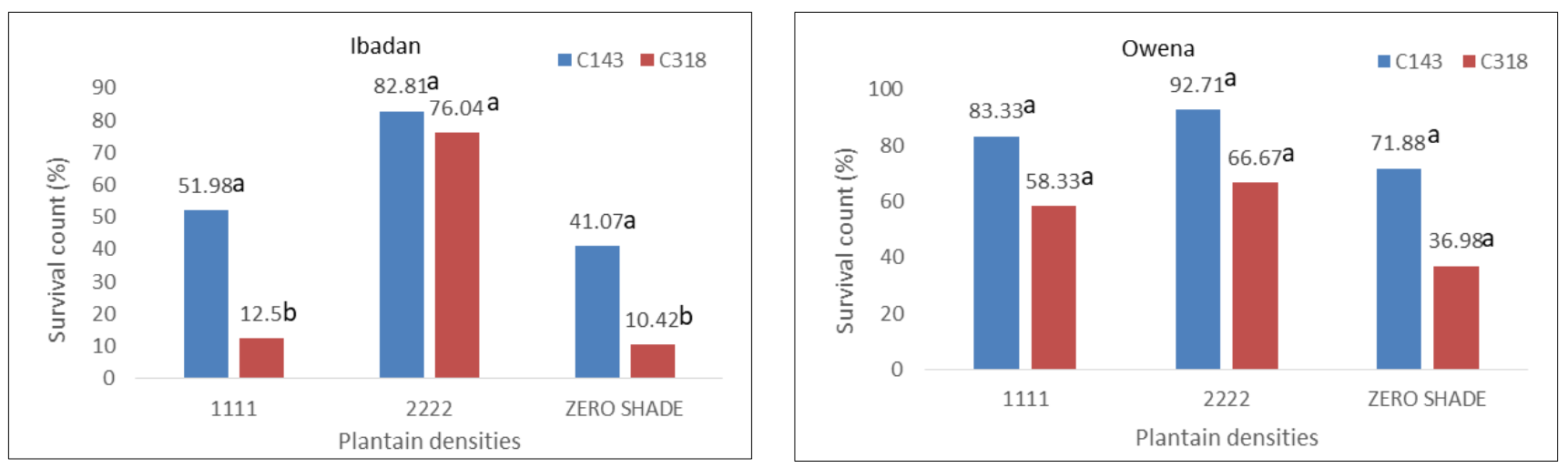

Means followed by the same letters in each composite graph are not significantly different by LSD ( $\mathrm{P}=0.05)$ C143: cultivar 143; C318: cultivar 318; 1111: 1111 plantain stands/ha; 2222: 2222 plantain stands/ha

Figure 2 Interaction effects of cultivar and plantain density on survival count of tea plants at Ibadan and Owena 


\section{Conclusion}

Growing tea under plantain shade enhanced its growth and seedling establishment at Ibadan and Owena. The growth and seedling establishment of cultivar 143 was better than that of 318 under all the plantain shade regimes, but its optimum was attained under 2222 plantain density ha-1. Tea growth performance was enhanced at Owena than at Ibadan. It is therefore recommended to prospective tea farmers in Southwest Nigeria that C143 should be preferred to C318, and that growing it under 2222 plantain ha-1 density would enhance its growth and early field establishment.

\section{Compliance with ethical standards}

\section{Acknowledgments}

The authors appreciate the Management of Cocoa Research Institute of Nigeria, Ibadan, for supplying the fund for the execution of this research work

\section{Disclosure of conflict of interest}

There is no conflict of interest

\section{References}

[1] Martins LC. Tea: The Drink that Changed the World. 2007; 8.

[2] Odom D. Cammelia sinensis. The Tea Plant. The Cammellia Journal. June - August 2007; 18.

[3] Mitscher L, Pillai S, Pillai C and Shankel D. Antibiotic resistance preventive properties of green tea. Proceedings of International conference on 0-Cha (Tea) Culture and Science, Shizuoka, Japan. October 5-8 2001; 1-4.

[4] Yayabe F. Industrial application of tea extracts. Proceedings of International conference on O-Cha (Tea) Culture and Science, Shizuoka, Japan. October 5-8 2001; 80-83.

[5] Juneja LK. Green tea: A storehouse of exciting nutraceuticals. Proceedings of International conference on 0-Cha (Tea) Culture and Science Shizuoka, Japan. October 5-8, 2001; 76-79.

[6] Friedman M, Mackey BE, Kim NJ, Lee IS, Lee KP Lee SU, Kozukue K, Kozukue N. Structure-activity relationship of tea compound against human cancer cells. J. Agric. Food Chem. 2007; 55: 243-253.

[7] Pham T. How tea travels from China to Africa. Ezen Articles. 2012; 1-3.

[8] FAO (Food and Agriculture Organization of the United Nations). FAOSTAT. 2014

[9] Bonheure D. TEA. The Tropical Agriculturist. (Macmillan Ltd. 1991). 1991; 1-54.

[10] Oloyede AA, Olaniyi 00, Adeosun OA, Muyiwa AA, Akanbi OSO. Variability of selected tea genotypes (Camellia sinensis) to stem cutting propagation in Nigeria. Conference Proceeding: 38th Annual Conference of the Genetics Society of Nigeria. 2014; 546-551.

[11] Oloyede AA, Olaniyi 00, Adeosun SA, Adeigbe 00. Effect of locations, clones on biochemical constituents of tea leaves in Nigeria. Proceeding of the 51st Annual Conference of the Agricultural Society of Nigeria, Abuja. 2017; 227-230.

[12] TRI. Shade in tea. The Tea Research Institute of Sri Lanka Advisory Circular. 2003; Serial No.3/03: 1-8.

[13] Janendra WA, De Costa M, Mohotti AJ, Wijeratne MA. Ecophysiology of Tea. Braz. J. Plant Physiol. 2007; 19(4): 13.

[14] Zhang WJ, Liang YR, Zhang FZ, Chen CS, Zhang YG, Chen RB, Wang BQ. Effects on yield and quality of oolong tea by covering with shading net. J. Tea Sci. 2004; 24: 276-282.

[15] Wang KR, Li NN, Su YY, Liang YR. Effect of sunlight shielding on leaf structure and amino acids concentration of light sensitive albino plant. African Journal of Biotechnology. 2013; 12(36): 5535-5539.

[16] Yunsheng Wang, Li Ping Gao, Fao Xia. Influence of shade on flavonoid biosynthesis in tea (Camellia sinensis (L) O. Kuntze). Scientia Horticulturae 141. 2012; 7-16. 
[17] Zhang Q, Shi Y, Ma L, Yi X, Ruan J. Metabolomic Analysis Using Ultra-Performance Liquid ChromatographyQuadrupole-Time of Flight Mass Spectrometry (UPLC-Q-TOF MS) Uncovers the Effects of Light Intensity and Temperature under Shading Treatments on the Metabolites in Tea. 2014; PLoS ONE 9(11): e112572.

[18] Owuor PO, Othieno CO, Howard GE, Robinson JM, Cooke RD. Studies on the use of shade in tea plantations in Kenya: Effects on chemical composition and quality of made tea. J. Sci. Food Agriculture. 1988; 46: 63-70.

[19] Ku KM, Choi JN, Kim J, Yoo LG, Lee CH. Metabolomics analysis reveals the compositional differences of shade grown tea (Camellia sinensis L.). J Agric. Food Chem. 2010; 58: 418-426.

[20] Bermudex MM. Erosion hidrica y escorrentia superficial en el sistema de café (Coffea Arabica L.) por (Erythrina poepigiana (Walper) O.F. Cook) en Turrialba, Costa Rica. MSc. Thesis Turrialba/Costa Rica. CATIE-UCR. $1980 ; 74$.

[21] Santana MB, Cabala PX. Reciclagem de nutrients emu ma plantacao de cacao sombreada com Eritrina. In: Proc IX Int coca Res Conf, Togo. 1984; 205-2010.

[22] Wiersium KF. Surface erosion under various tropical agro-forestry systems. In: O’Loughlin CL, Pearce AJ, eds, Symposium on effects of forest land use on erosion and slope stability. 1984; 231-239.

[23] Escalante G, Herrera R, Aranguren J. Fijacion de nitrogeno en arboles de sombre (Erythrina poeppigiana) en cacaotales del Norte de Venezuela. Pesqui Agropecu Bras 19. 1984; 223-230.

[24] Iremiren GO, Ipinmoroti RR, Daniel AM. Effect of shade management on tea cutting survival in two lowland agroecological areas in Nigeria. The 4th International Conference on O-CHA (Tea) Culture and Science Abstracts, October 26-28, 2010; 49.

[25] Velenzuella H. Pigeon peas: A multipurpose crop for Hawaii. In: Hana'Ai/The Food Provider. $2011 ; 1$.

[26] Famaye AO, Iremiren GO, Akanbi OSO, Aiyegboyin KO, and Adejobi KB. Effects of Plantain (Musa species) as shade on growth performance of cocoa seedlings in the nursery at Ibadan, Southwest Nigeria. Natural Science. 2014; 6: 447-453.

[27] CRIN (Cocoa Research Institute of Nigeria) Weather reports. 2016.

[28] OSAR (Ondo State Agro-Climatological Report). 2016.

[29] STAR (Statistical Tools for Agricultural Research). 2013.

[30] Annual Report of the Cocoa Research Institute of Nigeria. 1983; 47-56.

[31] Hajiboland R, Bastani S, Rad SB. Effect of light intensity on photosynthesis and antioxidant defence in boron deficient tea plants. Acta Biologica Szegediensis. 2011; 55(2): 265-272.

[32] Mohotti AJ, Lawlor DW. Diurnal variation of Photosynthesis and Photoinhibition in tea: effect of irradiance and nitrogen supply during growth in the field. J. Exp. Bot. 2002; 53: 313-322.

[33] Obatolu CR, Ipinmoroti RR. The comparative study of five clones under plantain shade in Ibadan, South-Western Nigeria. Proc. 18th HORTSON Conference. IAR/ABU, Zaria. 2000; 207-211.

[34] Annual Report of the Cocoa Research Institute of Nigeria. 1985; 55-69.

\section{Author's short biography}

\begin{tabular}{|l|l|} 
Dr. Seun Adewale Adeosun was born on 27 August 1969 in Iwo, Osun State, Nigeria. He obtained \\
B.Agric (Crop Production and Crop Protection) from Federal University of Agriculture Abeokuta, \\
Abeokuta, Nigeria in 1998; MSc. (Environmental Biology) and PhD. (Crop Physiology) from \\
University of Ibadan, Ibadan, Nigeria in 2006 and 2021, respectively. He began his research career \\
in Cocoa Research Institute of Nigeria, Ibadan in 2010 as a Research Officer 1. He is presently a \\
Principal Research Officer with over 20 research publications on Cocoa, Cashew, Coffee, Kola and \\
Tea in both local and international journals
\end{tabular}

